\title{
EXCESS CAPACITY AND ENTRY DETERRENCE: THE CASE OF MALAYSIAN PALM OIL REFINING INDUSTRY
}

\author{
CHOO SZE YI \\ SUHAILA H. A. JALIL \\ Faculty of Economics and Management \\ Universiti Putra Malaysia
}

\begin{abstract}
This paper empirically examines the relationship between excess capacity and probability of entry into Malaysian palm oil refining industry using time series data. Capacity and production, two components crucial to the study of excess capacity, were included in the estimation model. The analysis was conducted specifically in the Malaysian palm oil refining industry and the sample covered the period from 1976 to 2011. Logit model was employed in this analysis, where the results exhibited that excess capacity does not significantly influence probability of entry into the palm oil refining industry in Malaysia.
\end{abstract}

Keywords: Palm oil refining industry, excess capacity, entry deterrence.

\section{Introduction}

Oil palm tree, known as Elaies Guineensis Jacq., originated from West Africa. The oil extracted from the flesh of the palm fruit is what is called as the actual palm oil. Palm oil is used widely in many food products as well as in non-food products. Palm oil refining industry came in to the picture following the nation's diversification of the national economic plan to become an industrialised country. The pioneer of the Malaysian palm oil refining industry was Lam Soon Group, in which it started its operation in 1970 followed by establishments such as Lever Brothers (Malaysia) and Senawang Edible Oils. Soon after in 1976, Malaysia gained the status as world's largest palm oil refining country following rapid expansion and development of the palm oil refining industry.

Today, more than three decades after the inception of oil palm refining industry, 56 refineries were in operation with a total capacity of 24.9 million tonnes in $2011 .{ }^{1}$ Based on the statistics provided by MPOB, in year 2011 itself, a total of 30.6 million tonnes of processed oil was produced domestically in Malaysia. The massive increase in palm oil refining and the amount of capacity produced had strengthened Malaysia's position as a leading producer accounting for $37 \%$ of world palm oil production and $46 \%$ of world's palm oil exports in 2011. It is also believed worldwide acceptance of palm oil is brought up by the growth and development of palm oil refining industry in Malaysia, where of 49 million tonnes of palm oil consumed globally, Malaysia supplied approximately $46 \%$ of palm oil to the world market (MPOB, 2011).

Despite the fact that the Malaysian palm oil refining industry has been progressing well, its performance was rather discouraging as compared to Indonesia that is speeding up their performance in this industry. Malaysia lost its position as the biggest producer in the world with total production of 15.8 million tonnes to Indonesia with 16 million tonnes in 2006 and the latter has led ever since. According 
to statistics provided by MPIC (2011), the production capacity of Indonesia was 23.9 million tonnes, compared to Malaysia's 18.9 million tonnes, which suggests that there is room for improvement for the domestic industry. It is therefore important to plan and deploy strategies to ensure the development of palm oil refining industry in this country. Moving forward, the strategies to invest in excess capacity are hoped to contribute toward restoring Malaysia's status as the world's largest palm oil producer.

According to CEO of Palm Oil Refiners Association of Malaysia, Mohammad Jaaffar Ahmad, the existence of excess capacity is crucial to domestic palm oil industry as it helps to ensure a sufficient and continuous supply of palm oil for further processing and refining. The issue of excess capacity had long existed in the Malaysian palm oil refining industry when Abdul Jalil (1996) affirmed evidence of excess capacity in the industry. The author believed that the fluctuation in the international demand and prices of processed palm oil had caused refineries in the industry to invest in excess capacity. Excess capacity is a situation in which the industry is producing below current demand of the market. Excess capacity is often found in natural monopoly or oligopolistic markets with moderate to high government or agency intervention. This may occur when demand is high and firms need to invest in excess capacity with the intention of deterring or preventing new entry into the market. It is a strategy for established firms to be competent in supplying the amount demanded, should the demand increase (Kulatilaka \& Perotti, 1992; Gabszewics \& Poddar, 1997, Hay \& Liu, 1998; Driver, 2000; Besanko, Doraszelski, Lu, \& Satterthwaite, 2010; Kadiyali \& Conlin, 2006; Bagchi \& Mukherjee, 2011).

Excess capacity is known as one of the barriers to entry that enables the incumbent to enjoy economies of scale and cost advantages in its production upon entrant's entry. The barriers and cost advantages act as shields for incumbents against new firm's advancement into the market. Given the circumstance, an established firm is able to price its product above its cost to earn profit. Theoretically, excess capacity is often associated with inefficient allocation of resources, higher prices, restricted output, and unreasonably high production cost which is not beneficial from consumers' perspective. On the other hand, it is said that excess capacity can be a good thing for consumers, as they do not have to worry about price inflation (Davis, 2002). This is because firms with excess capacity would eventually decrease price or minimise price increase in order to boost their sales in the market.

It can also be used by incumbents to deter an entry to stay longer in the industry or to eliminate competition of the new entrants. Excess capacity works as a tool to deter or eliminate entry in that it ensures established firms the capabilities to produce in a larger scale at a lower cost of production. The durability of established firms in the market can as a result be extended. Excess capacity increases liberalisation of trade as well, where it enables domestic firms to venture into the global market and compete with foreign or big multinational firms in sustaining the production and quality of goods.

The main purpose of this paper is to address the central question of how can excess capacity in palm oil refining industry in Malaysia work as a strategy to deter entry into the industry? The general objective of the study was to determine the use of excess capacity to deter entry into the palm oil industry using a logit model. The next section outlines the theoretical and empirical literature on the uses of excess capacity. Section 3 and 4 outline the model used for the purpose of this study and empirical results obtained respectively. Section 5 summarises the findings of this study.

\section{Theory and Prior Empirical Evidences}

The literature suggested that firms with excess capacity can deter further entry, or at least reduce the scale of entry into the market. Spence (1977), Dixit (1980), Spulber (1981), Osborne and Pitchik (1987), Bulow, Geanakoplos, and Klemperer (1985), Allen, Deneckere, Faith, 
and Kovenock (2000), and Röller and Sickles (2000) in their studies emphasised the strategic effect of excess capacity in deterring entry. Excess capacity is more likely to be chosen as a strategy, in which high cost of capacity and high fixed set up costs are factors that burden and deter an entrant's entry according to Bagchi and Mukherjee (2011). Potential entrants may view excess capacity as a threat for them to enter the market as suggested by Wenders (1971), Spence (1977) and Kottinen (2002). Excess capacity enables incumbents' immediate reaction to reduce price by expanding output when entry occurs, where the probability of entry is decreased due to reduction of entrant's revenue. By pricing the product at a lower price, incumbents are inducing entrants to follow suit by directly decreasing the revenue earned and indirectly reducing the probability of entry.

Similar conclusions were drawn by Gelman and Salop (1983) and Tirole (1988), where they believed that incumbents maintain excess capacities to make their rivals reduce output levels. Later on, Conrad and Veall (1991) confirmed that capacity held by established firms are to discourage rivals that are in the market from expanding. The works of Maskin and Tirole (1988) and Kottinen (2002) had rather contrasted with conclusions made by the scholars above, where the former found that entrants invest in excess capacity to induce exit of incumbent instead, and the latter believed excess capacity encouraged firm's entry, respectively. Firms in unforeseeable market have the tendency to invest in excess capacity as indicated by Kulatilaka and Perotti (1992), Gabszewics and Poddar (1997), and Maskin (1999) where they observed firms invest more as precautionary move for the unknown future. Similarly, Wood (2005) claimed that excess capacity is unlikely to occur in a stable market demand environment.

As pointed out by Henderson and Cool (2003), firms improve competitiveness by expanding their capacity. DuPont Company used the strategy of expanding capacity to influence and retard opponents' plan to expand their capacity (Ghemawat, 1984). Likewise, Fussilio (2002) stated that the higher the propensity of entrant to entry, the more capacity would be invested by incumbent firms. Recent work by Tay (2005) discovered that firms did invest in excess capacity to strategically reduce other firms' output as seen in the Taiwanese flour industry.

Studies done by Waldman (1987), and Kadiyali and Conlin (2006) showed that large market share firms tend to hold more capacity to deter entry as well as to further increase its market share. According to Esposito and Esposito (1974), and Kirman and Masson (1986), firms in moderately high concentration industry appeared to install excess capacity more often than those in very concentrated ones did. Conversely, Hannan and Torries (1989) argued that firms in high concentration industry apparently invest in excess capacity as it is seen as a way to remain competitive in the market. Nevertheless, Masson and Shaanan (1986) found no significant relationship between investment in excess capacity and market concentration.

Excess capacity may have caused or assisted the occurrence of collusive behaviour, as suggested by Cowling (1983), Brock and Scheinkman (1985), and Bagchi and Mukherjee (2011). A different interpretation was made by Scherer and Ross (1990) where they explained that collusive or cartel behaviour may in turn lead firms to invest in excess capacity. Firms may be restricted from producing its potential level of output in cartel arrangement, thus the existence of excess capacity in production.

The work of Spulber (1981) stated that the incumbent firm with first mover advantage in the market invested in idle capacity to deter entry, while Spence (1977) concluded that firms that invested in excess capacity would resume producing in full capacity post-entry. This led Dixit (1980) to criticise Spence's work and argued that idle capacity does not appear as a credible threat deterrent. ${ }^{2}$ The point raised by Dixit (1980) was supported by Bulow et al. (1985) in that capacity would be left idle at the end of the day when entry is deterred. On the contrary, Wilson (1992) and Mathis and Koscianski (1996) proved in their research that 
excess capacity did reduce the probability of entry where the latter focused their studies in the titanium metal industry in United States.

Despite all the works that supported the notion of excess capacity as a significant deterrence tool, Masson and Shaanan (1986), Lieberman (1987), Christensen and Caves (1997), and Carree (2007) rejected the usefulness of excess capacity to deter entry. Christensen and Caves (1997) added that announcement of excess capacity in fact attracts competition by other firms in the industry.

\section{Estimation Model}

This study used annual time-series data involving capacity, production and number of refineries in Malaysia of each year from 1976 to 2011, which were extracted from statistics in PORLA Annual Report (1976-1988) prepared by the Palm Oil Registration and Licensing Authority (PORLA) and Malaysian Oil Palm Statistics (1986-2011) and published by the Malaysian Palm Oil Board (MPOB).

\section{Logit Model}

The profitability that an entrant foresees in the business is an important determinant for a firm to enter a particular market. It is obvious that the decision of a firm to enter an industry is that of "to enter" or "not to enter", where it is called a dichotomous decision as quoted from Mathis and Koscianski (1996). The so-called dichotomous decision can be analysed empirically through a binary dummy variable in which "one" is labeled as the occurrence of entry while "zero" is represented as no occurrence of entry. Referring to the studies by Mathis and Koscianski (1996), the logit model was employed in predicting the probability of occurrence of an event. In this analysis, the entry of a firm was the dependent variable, while independent variables were capacity, production and number of firms in the palm oil refining industry. The probability of the occurrence event of entry, $P_{t}$ is specified as:

$$
\begin{aligned}
P_{t} & =E\left(Y_{t}=1 \mid X_{1, t}, X_{2, t}, X_{3, t}\right) \\
& =\frac{e^{\beta_{0}+\beta_{1} X_{1, t}+\beta_{2} X_{2, t}+\beta_{3} X_{3, t}}}{1+e^{-\beta_{0}+\beta_{1} X_{1, t}+\beta_{2} X_{2, t}+\beta_{3} X_{3, t}}}=\frac{e^{z}}{1+e^{z}}
\end{aligned}
$$

with $e$ being the base of natural logarithm. The probability that entry does not occur is represented by:

$$
1-P_{t}=1-\frac{e^{z}}{1+e^{z}} \quad=\frac{1+e^{z}-e^{z}}{1+e^{z}} \quad=\frac{1}{1+e^{z}}
$$

To compute the ratio of probability of entry occurrence to the probability of no entry occurrence, $L_{t}$ was obtained by dividing Equation (1) by Equation (2), which produced the equation as below:

$L_{t}=\frac{P_{t}}{1-P_{t}}=\frac{e^{z}}{1+e^{z}} \cdot \frac{1+e^{z}}{1}=e^{z}$

For estimation purposes,

$L_{t}=\ln \left(\frac{P_{t}}{1-P_{t}}\right)=z=\beta_{0}+\beta_{1} X_{1, t}+\beta_{2} X_{2, t}+\beta_{3} X_{3, t}+\mu_{t}$

(Gujarati, 2003).

Following Mathis and Koscianski (1996), the specific logit model to be estimated in this paper is represented by:

$E N T R Y_{t-n}=\delta_{1} C A P_{t-n}+\delta_{2} P_{R O D} t-n+\delta_{3} F_{I R M S}+\mu_{t}$

where, $E N T R Y_{t-n}$ represents the natural log of the probability of firm entry in year $t-n$ divided by the probability of no entry occurrence in year $t-n$. The independent variables, $C A P_{t-n}$ and $P R O D_{t-n}$, represent the one-year, two-year and threeyear lags (averages) of values or capacity and production respectively. The FIRMS variable is included as a control variable so that changes in $C A P_{t-n}$ and $P R O D_{t-n}$ pertains only to incumbent firm's behaviour. The empirical results obtained from this logit model are explained in detail in the following section.

\section{Augmented Dickey-Fuller (ADF) Test}

The data set used in this analysis is a time-series data for 1976 to 2011. As with any time-series 
data, the potential problem of non-stationarity exists. Specifically, the mean, variance, and covariance of these variables may change over time, invalidating traditional hypothesis-testing techniques. Accordingly, it is necessary to apply Augmented Dickey-Fuller (ADF) tests to each of the single series to ensure the stationarity of the variables.

The stationarity of the series is needed to circumvent spurious regression. Stationarity could be achieved by an appropriate number of differencing, which is called order of integration. Augment Dickey-Fuller (ADF) test can be used to check the stationarity of the variables (Dickey \& Fuller, 1979). The following equation is considered in estimating the regression:

$$
Y_{t}=\beta_{0}+\beta_{1} Y_{t-1}+\sum_{i=0}^{\rho} \beta_{i+2} \Delta Y_{t-i-1}+\varepsilon_{t}
$$

where,

$Y_{t}=$ each of the variables to be tested separately (capacity and production); $\rho=$ number of lagged differences in $Y ; \Delta=$ differencing operator; $t=$ time trend; and $\varepsilon_{t}=$ white noise residual of zero mean and constant variance.

The hypothesis to be tested was that:

$$
\begin{aligned}
& H_{0}: \beta=1 \text { or } \delta=1-\beta_{1}=0 \text { (implies } Y_{t} \text { is } \\
& \text { non-stationary or a unit root process }) \\
& H_{l}: \beta<0\left(Y_{t}\right. \text { is stationary) }
\end{aligned}
$$

Testing for stationarity of the first differences involves estimating the regression:

$$
\Delta Y_{t}=C_{0}+C_{1} \Delta Y_{t-1}+\sum_{i=0}^{\rho} C_{i+2} \Delta\left(\Delta Y_{t-i-1}\right)+\varepsilon_{t}
$$

The $\Delta s$ represents the first difference of the variables to be tested. The relevant hypothesis for this test is in the following:

$$
\begin{aligned}
& H_{0}: C_{1}=\delta=1-C_{1} \text { or } 0 \text { (implies } \Delta Y_{t} \text { is a } \\
& \text { non-stationary or a unit root process) } \\
& H_{0}: C_{1}<O\left(\Delta Y_{t}\right. \text { is stationary). }
\end{aligned}
$$

\section{Results and Discussion}

Based on the ADF test in Table 1, the t-statistics for the two variables tested for palm oil refining industry in Malaysia was statistically insignificant to reject null hypothesis of nonstationary at both "trend" and "no trend" condition in the level for one-year lag, two-year lag, and three-year lag. This indicated that these series are non-stationary at their level form. Therefore, either these variables contain a unit root process, or they share common stochastic movement and would need higher degree of differencing.

When the ADF test was conducted at one-year lag first difference of the average capacityl and average production1, the result demonstrated that all variables are stationary at $1 \%$ significance level. For the two-year lag average capacity 2 and average production 2 data, results showed that all variables were stationary at $5 \%$ significance level, at first differencing. Lastly, for the results for three-year lag average capacity 3 and average production 3 data demonstrated that both variables are stationary at $5 \%$ and $10 \%$ significance level in the first differencing respectively. Therefore, since the DurbinWatson statistics obtained were close to the value of 2.0 , no correction for serial correlation was required. It was concluded that the average capacity and average production for this data set are integrated of order one I(1), and a higher order of differencing was not required to execute for both the trend and no trend conditions. The results above implied that the time series data used for this study is stable and does not change or fluctuate over time. 
Table 1

ADF Test and Cointegration Test Result

ADF Test

Level

First Diff

\begin{tabular}{|c|c|c|c|c|}
\hline \multirow{2}{*}{ Variable } & \multicolumn{2}{|c|}{ Lent } & \multicolumn{2}{|c|}{ 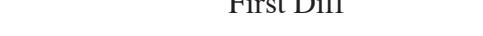 } \\
\hline & No trend & Trend & No trend & Trend \\
\hline Avg Cap1 & 0.439129 & $-5.513236 * * *$ & $-6.208606 * * *$ & $-5.870834 * * *$ \\
\hline Avg Prod 1 & -0.448396 & $-4.751064 * * *$ & $-6.460582 * * *$ & $-5.972013 * * *$ \\
\hline Avg Cap2 & 1.954844 & -2.350341 & $-2.586194 * *$ & $-3.765696 * *$ \\
\hline Avg Prod 2 & 1.329133 & $-3.491077 * *$ & $-2.072791 * *$ & $-5.888057 * * *$ \\
\hline Avg Cap3 & 0.548865 & -2.611530 & $-2.268024 * *$ & $-3.515412 * *$ \\
\hline Avg Prod3 & 0.517039 & -0.409372 & $-1.197905 *$ & $-5.974802 * * *$ \\
\hline
\end{tabular}

\section{Cointegration Test}

\begin{tabular}{cc} 
Variable & Durbin-Watson Statistic \\
\hline AVCAP1 & 2.405748 \\
AVPROD1 & 1.827707 \\
\hline AVCAP2 & 1.858886 \\
AVPROD2 & 1.778599 \\
\hline AVCAP3 & 1.835787 \\
AVPROD3 & 1.986938
\end{tabular}

Note. ${ }^{* * *}, * *$ and $*$ indicate the rejection of null hypothesis of non-stationary at $1 \%, 5 \%$ and $10 \%$ significance level.

\section{Analysis on Logit Model}

The logit model used here is to estimate probability of entry in the industry and it assumes the value of Entry $=1$ if the event of entry occurs, or Entry $=0$ if the event of entry does not occur. The probability of an event of entry to occur indicates that excess capacity invested does not deter entry of other firms into the industry, while the value of Entry $=0$ signifies that excess capacity does work as a strategy to deter entry of new entrants.
The result of the logit test for the sample from 1976 to 2011 is reported in Table 2. As explained by Mathis and Koscianski (1996), it is necessary to put lag for these variables as potential entrants may take some time to observe and decided whether entry is favourable to them or otherwise. It may take up to several years of observation and planning before an entrant decides to enter, thus one-year lag (AVCAP1, AVPROD1), twoyear lag (AVCAP2, ACPROD2), and three-year lag (AVCAP3, AVPROD3) were added in the estimation. The interpretation of the logit model 
differs from other tests or models. It should be noted that, the expected signs of the regression coefficients are the most important aspect of logit model (Gujarati, 2003). One should first interpret the expected signs of the regression coefficients.

Based on the result in Table 2, the value of coefficient for one-year lag suggested a negative relationship between capacity and entry. This is to say, when the value of capacity increase, the probability of entry would thus decrease. Coefficients for AVCAP2 and $A V C A P 3$ record negative values that implied negative relationships between capacity and entry respectively, which is consistent with Koscianski and Mathis (1995) and Mathis and Koscianski (1996). They confirmed that an entrant's decision to enter is driven by the excess capacity in the industry as it serves as an effective barrier. They reasoned that excess capacity held by incumbents deters and retard entrant's progress into the market by threatening to increase production and reduce prices to greatly cut the entrant's profit upon entry.

The regression coefficient of AVPROD1, $A V P R O D 2$ and AVPROD3 implied a positive relationship between production and entry, in which, with an increase in production, probability of entry increases. The positive sign on the variable of number of firms, FIRMS1, FIRMS2, and FIRMS3, indicated that as the number of firms in the industry increases, entry is more likely to occur. These variables exhibit the same signs and are consistent with the results by Mathis and Koscianski (1996) in studying the titanium industry in the United States. Despite the signs of coefficients that are consistent with those found in literatures, looking at the z-statistics for the variables tested in palm oil refining industry in Malaysia, all the variables tested were statistically insignificant. This signifies that excess capacity does not work as an effective tool to deter entry in the palm oil refining industry in Malaysia.

Table 2

Logit Analysis

\begin{tabular}{ccc}
\hline Variable & Coefficient & z-Statistic \\
\hline AVCAP1 & -0.128800 & 0.446583 \\
AVPROD1 & 0.285804 & -0.547391 \\
FIRMS1 & 0.911345 & -0.621277 \\
\hline AVCAP2 & -3.304505 & -1.109100 \\
AVPROD2 & 1.077798 & 0.442181 \\
FIRMS2 & 4.502099 & 1.265318 \\
AVCAP3 & -4.135685 & -1.221641 \\
AVPROD3 & 1.488713 & 0.550335 \\
FIRMS3 & 5.657446 & $2.381752 *$ \\
\hline
\end{tabular}

Note. * Indicates significance at $10 \%$ level.

Although the use of excess capacity does not work as a credible threat in to deter entry into the palm oil industry in Malaysia, it still works as a strategy to deter entry in the United States titanium industry as supported by Mathis and Koscianski (1996) using a logit model. This 
could probably be due to the nature of operational policy in the palm oil industry, in Malaysia particularly. As palm oil is the backbone of the Malaysian economy, the government's involvement is somewhat extensive compared to other industries and other countries. With the purpose to preserve the industry, government agency (MPOB) has the sole power in distributing licenses to the palm oil refineries, which may deny the competitive structure of the industry that is much needed for the significant outcome of excess capacity to work effectively.

\section{Conclusion}

The aim of this paper was to comprehensively examine the relationship between excess capacity and probability of entry deterrence in the Malaysian palm oil refining industry. The results of the logit model indicated that all the coefficients showed the correct expected signs. According to Gujarati (2003), it should be noted that the expected signs of the coefficients are crucially important in analysis of logit. The variable results were however insignificant and it proved that excess capacity does not work to deter entry in the Malaysian palm oil industry. The government's involvement in the industry is believed to have contributed to the insignificant results for the above analysis. The palm oil industry is a regulated industry in which the government has control over the production, capacity, and licensing of entrance of firms. This intervention overrules the possibility of free entry or exit of firms in the said industry, thus may impede the use and the effectiveness of excess capacity in barricading entry of new firms into the industry as a whole.

\section{End Notes}

1 As of 2011, the palm oil refining industry in Malaysia was represented by 56 operating refineries. With 38 refineries in Peninsular Malaysia and the remaining 18 refineries in Sabah and Sarawak producing a huge amount of oil production for world consumption.
2 Dixit (1980) believed that in times of entry, incumbent firms would increase production to bring the price down, but would eventually reduce output production, as the drop in prices would affect them also. He thus concluded that excess capacity does not work as a threat since capacity would remain idle post-entry.

\section{References}

Abdul Jalil, S. (1996). Capacity utilisation in the Malaysian palm oil refining industry (Unpublished doctoral dissertation). Bangi: Universiti Putra Malaysia.

Allen, B., Deneckere, R., Faith, T., \& Kovenock, D. (2000). Capacity pre-commitment as a barrier to entry: A Bertrand-Edgeworth approach. Economic Theory, 15(3), 501530.

Bagchi, A., \& Mukherjee, A. (2011). Commitment and excess capacity with licensing: An old debate with a new look. Journal of Economics, 103(2), 133-147

Besanko, D., Doraszelski, U., Lu, L.X., \& Satterthwaite, M. (2010). On the role of demand and strategic uncertainty in capacity investment and disinvestment dynamics. International Journal of Organization, 28(4), 383-389.

Brock, W.A., \& Scheinkman, J.A. (1985). Price setting supergames with capacity constraints. The Review of Economic Studies, 52(3), 371-382.

Bulow, J., Geanakoplos, J., \& Klemperer, P. (1985). Holding idle capacity to deter entry. The Economic Journal, 95(377), 178-182.

Carree, M. A. (2007). On factors promoting and hindering entry and exit. In S. Parker (Ed.), International handbook series on entrepreneurship (Volume 3, pp. 161183). New York: Springer United States.

Christensen, L. R., \& Caves, R. E. (1997). Cheap talk and investment rivalry in the pulp and paper industry. The Journal of Industrial Economics, 45(1), 47-73.

Conrad, K., \& Veall, M. R. (1991). A test for strategic excess capacity. Journal of Empirical Economics, 16(4), 433-445. 
Cowling, K. (1983). Excess capacity and the degree of collusion: Oligopoly behaviour in the slump. The Manchester School of Economic and Social Studies, 51(4), 341-359.

Davis, E. (2002, December 23). What will 2003 bring? BBC News, Business World Edition. Retrieved from http://news.bbc. co.uk

Dickey, D. A., \& Fuller, W.A. (1979). Distribution of the estimators for autoregressive time-series with a unit root. Journal of the American Statistical Association, 74(366), 427-431.

Dixit, A. (1980). The role of investment in entry-deterrence. The Economic Journal, 90(357), 95-106.

Driver, C. (2000). Capacity utilization and excess capacity: Theory, evidence and policy. Review of Industrial Organization, 16(1), 69-87.

Esposito, F. F., \& Esposito, L. (1974). Excess capacity and market structure. The Review of Economics and Statistics, 56(2), 188-194.

Fussilio, M. (2002). Excess capacity and entry deterrence: The case of ocean liner shipping markets. Paper presented at International Association of Maritime Economists (IAME) Conference 2002, Panama 13-15 November (pp. 20-41).

Gabszewicz, J. J., \& Poddar, S. (1997). Demand fluctuations and capacity utilization under duopoly. Economic Theory, 10(1), 131-146.

Gelman, J. R., \& Salop, S. C. (1983). Judo economics: Capacity limitation and coupon competition. The Bell Journal of Economics, 14(2), 315-325.

Ghemawat, P. (1984). Capacity expansion in the titanium dioxide industry. The Journal of Industrial Economics, 33(2), 145-163.

Gujarati, D. (2003). Basic econometric (4th ed.). New York: McGraw-Hill.

Hannan, M. J., \& Torries, T. F. (1989). Industry structure and capacity. In J. A. Cordes \& T. F. Torries (Eds.), Surplus capacity in the international metals industry (pp. 1-12). Littleton, Colorado: Society for Mining Metallurgy.
Hay, D. A., \& Liu, G. S. (1998). The investment behavior of firms in an oligopolistic setting. The Journal of Industrial Economics, 46(1), 79-99.

Henderson, J., \& Cool, K. (2003). Learning to time capacity expansions: An empirical analysis of the worldwide petrochemical industry 1975-1995. Strategic Management Journal, 24(5), 393-413.

Kadiyali, V., \& Conlin, M. (2006). Entry deterring capacity in the Texas lodging industry. Journal of Economics and Management Strategy, 15(1), 167-185.

Kirman, W. I., \& Masson, R. T. (1986). Capacity signals and entry deterrence. International Journal of Industrial Organization, 4(1), 25-42.

Koscianski, J., \& Mathis, S. (1995). Exccess capacity and the probability of entry: An application to the US titanium industry. Resource Policy, 21(1), 4351.

Kottinen, J. (2002). Excess capacity as entry deterrence (Online paper). Retrieved from https://helda.helsinki.fi

Kulatilaka, N., \& Perotti, E. C. (1992). Strategic investment timing under uncertainty. Working paper, Boston University.

Lieberman, M. B. (1987). Excess capacity as a barrier to entry: An empirical approach. The Journal of Industrial Economics, 35(4), 607-627.

Malaysian Palm Oil Board (MPOB). Malaysian oil palm statistics (Various issues, 1986-2011). Kuala Lumpur: Ministry of Primary Industries.

Maskin, E. S. (1999). Uncertainty and entry deterrence. Economic Theory, 14(2), 429-437.

Maskin, E. S., \& Tirole, J. (1988). A theory of dynamic oligopoly, I: Overview and quantity competition with large fixed costs. Econometrica, 65(3), 549-569.

Masson, R. T., \& Shaanan, J. (1986). Excess capacity and limit pricing: An empirical test. Economica, New Series, 63(211), 365-378.

Mathis, S., \& Koscianski, J. (1996). Excess capacity as a barrier to entry in the 
US titanium industry. International Journal of Industrial Organization, 15(2), 263-281.

MPIC. (2011). Statistics on commodities 2011. Putrajaya: Ministry of Plantation and Industries and Commodities.

Osborne, M., \& Pitchik, C. (1987). Cartel, profit and excess capacity. International Economics Review, 28, 413-428.

Palm Oil Registration and Licensing Authority (PORLA). (1976-1985). Annual Report PORLA Palm Oil Update (Various issues). Malaysia.

Röller, L.-H., \& Sickles, R. C. (2000). Capacity and product market competition: Measuring market power in a 'puppydog' industry. International Journal of Industrial Organization, 18(6), 845865.

Scherer, F. M., \& Ross, D. (1990). Industrial market structure and economic performance (3rd ed.). Boston: Houghton-Mifflin.

Spence, A. M. (1977). Entry, capacity, investment and oligopolistic pricing. The Bell Journal of Economics, 8(2), 534-544.
Spulber, D. F. (1981). Capacity, output and sequential entry. The American Economic Review, 71(3), 503-514.

Tay, C. M. (2005). Strategic investment and excess capacity: A study of the Taiwanese flour industry. Journal of Applied Economics, 8(1), 153-170.

Tirole, J. (1988). The theory of industrial organization. Cambridge, Massachusetts: MIT Press.

Waldman, M. (1987). Non-cooperative entry deterrence, uncertainty, and the free rider problem. The Review of Economic Studies, 54(2), 301-310.

Wenders, J. T. (1971). Excess capacity as a barrier to entry. The Journal of Industrial Economics, 20(1), 14-19.

Wilson, R. (1992). Strategic model of entry deterrence. In R. J. Aumann \& S. Hart (Eds.), The handbook of game theory with economic application, volume 1 (pp. 305-329). Amsterdam: Elsevier Science B.V.

Wood, A. (2005). Investment interdependence and the coordination of lumpy investments: Evidence from the British brick industry. Applied Economics, 37(1), 37-49. 